\title{
PERANCANGAN KEY PERFORMANCE INDICATORS SEBAGAI SISTEM PENILAIAN KINERJA DI PT. INTI ISAWIT SUBUR
}

\author{
Imam Bayhaqi ${ }^{*}$ \\ ${ }^{1}$ Program Studi Teknik Industri, Sekolah Tinggi Teknologi Nasional Jambi \\ *Korespondensi Penulis, E-mail: imambaihaqi67@gmail.com
}

$\begin{array}{ll}\text { Diterima } & : 22 \text { September } 2020 \\ \text { Disetujui } & : 2 \text { November } 2020\end{array}$

Direvisi : 4 Oktober 2020

\begin{abstract}
Abstrak
Perkembangan dunia industri yang pesat mendorong perusahaan untuk meningkatkan kinerjanya agar dapat bertahan dan berkembang. Sistem penilaian kinerja merupakan alat untuk melakukan evaluasi internal dan penilaian strategis. PT. Inti Isawit Subur mengukur kinerja perusahaannya hanya berdasarkan aspek keuangan saja sehingga tidak menggambarkan kinerja perusahaan secara keseluruhan. Metode yang digunakan dalam perancangan sistem penilaian kinerja di PT Inti Isawit Subur adalah Balanced Scorecard, karena metode ini menetapkan kriteria yang diukur menjadi empat perspektif yaitu Keuangan, Pelanggan, Proses Internal, dan Pembelajaran \& Pertumbuhan. Hasil perancangan sistem penilaian kinerja diperoleh 11 Key Performance Indicators kinerja utama. Perspektif keuangan terdiri dari 2 indikator yaitu meningkatkan profit dan meningkatkan investasi, perspektif pelanggan terdiri dari 3 indikator yaitu meningkatkan kepuasan konsumen, loyalitas konsumen, dan bertambah jumlah konsumen, perspektif proses internal terdiri dari 3 indikator yaitu meningkatkan jumlah produksi, mengurangi tingkat kecelakaan kerja, dan kehadiran karyawan, dan perspektif pembelajaran dan pertumbuhan terdiri dari 3 indikator yaitu meningkatkan kepuasan pegawai, meningkatkan kompetensi pegawai, dan penghargaan. Untuk melihat keterkaitan masing-masing perspektif, perusahaan dapat melihat peta strategi yang dapat memberikan gambaran untuk meningkatkan laba perusahaan.
\end{abstract}

Kata kunci: Balanced Scorecard, Key Performance Indicators, Sistem Penilaian Kinerja

\section{Pendahuluan}

Perkembangan dunia industri yang semakin cepat mendorong perusahaan untuk meningkatkan kinerjanya agar tetap bertahan dan berkembang. Setiap harinya muncul pelaku-pelaku industri yang memperkenalkan produk-produk usahanya, sehingga dunia industri dan bisnis saat ini semakin kompetitif. Ketika semuanya serba sulit, maka dituntut semangat untuk memecahkan kebuntuan tatanan sistem melalui cara-cara inovatif dan kreatif (creative destruction) [1]. Pelaku industri harus siap berkompetisi untuk mempertahankan industri dan bisnis yang dijalankan. Salah satunya dengan mempersiapkan sistem penilaian kinerja perusahaan. Perubahan yang cepat dalam persaingan, produksi, pemasaran, pengelolaan sumber daya manusia dan penanganan transaksi antar perusahaan dengan pelanggan dan perusahaan dengan perusahaan lain, menyebabkan pengukuran kinerja perusahaan menjadi hal yang penting bagi manajemen untuk melakukan evaluasi terhadap performa perusahaan sebagai perancanaan tujuan di masa mendatang.

Sistem penilaian kinerja merupakan alat untuk melakukan evaluasi internal dan penilaian strategis [2]. Dengan melakukan perancangan sistem penilaian kinerja dapat diketahui sejauh mana perusahaan telah mencapai tujuan yang telah ditetapkan sehingga dapat diketahui apa saja yang telah dilakukan dan yang belum dilakukan untuk melakukan perbaikan guna mencapai keberhasilan [3].

PT. Inti Isawit Subur merupakan perusahaan pengolahan minyak kelapa sawit yang terletak di wilayah Pasaman Barat Sumatra Barat. Saat ini perusahaan PT. Inti Isawit Subur melakukan pengukuran kinerja perusahaannya hanya berdasarkan pada aspek keuangan sehingga tidak menggambarkan kinerja perusahaan secara keseluruhan. Pengukuran kinerja keuangan hanya menilai kinerja untuk jangka pendek dan tidak memperhitungkan aktivitas manajemen yang tidak terlihat di perusahaan. 
Dalam penelitian ini akan merancang key performance indicators sebagai sistem penilaian kinerja dengan menggabungkan faktor keuangan dan non-keuangan.

Metode yang digunakan dalam melakukan perancangan key performance indicators di PT. Inti Isawit Subur adalah Balanced Scorecard, karena metode ini menetapkan kriteria yang diukur menjadi empat yaitu Financial, Customers, Internal Process, dan Learning and growth [4]. Keunggulan dalam penggunaan metode Balanced Scorecard yaitu penilaian atau kriteria yang digunakan adalah gabungan dari faktor keuangan dan non-keuangan, sehingga perusahaan mampu menilai kinerja manajemen dan kinerja keuangan perusahaan. Dengan metode ini perusahaan mampu melakukan perbaikan dan meningkatkan kinerja manajemen yang akan berpengaruh terhadap peningkatan profit perusahaan.

Dapat dirumuskan permasalahan dalam penelitian ini adalah, bagaimana perancangan sistem penilaian kinerja di PT. Inti Isawit Subur yang dapat digunakan untuk meningkatkan kinerja perusahaan sehingga memperoleh laba yang lebih baik.

\section{Landasan Teori}

\subsection{Pengukuran dan Penilaian Kinerja}

Pengukuran kinerja sangat dibutuhkan oleh perusahaan karena ini merupakan alat penting yang memungkinkan perusahaan untuk mencapai dan mengontrol tujuan yang diinginkan [5], sehingga dengan melakukan pengukuran kinerja dapat dilihat hubungan sebab akibat antara pengukuran kinerja yang di lakukan dengan hasil akhir yang diperoleh. Perusahaan telah memahami bahwa untuk dapat bersaing di lingkungan yang terus berubah perlu dilakukan pengukuran dan penilaian untuk mengetahui perkembangan perusahaan karena pengukuran ini sebagai elemen penting dalam meningkatkan kinerja [6].

Istilah efisiensi dan efektivitas digunakan secara tepat dalam konteks ini. Istilah efektivitas dalam pengukuran kinerja mengacu kepada sejauh mana kebutuhan pelanggan dapat terpenuhi sedangkan efisiensi dalam pengukuran kinerja merupakan ukuran dari seberapa ekonomis sumber daya perusahaan yang digunakan ketika memberikan kepuasan kepada pelanggan [7]. Untuk mencapai tingkat kinerja bisnis dari fungsi efisiensi dan efektivitas perlu melakukan tindakan sebagai berikut:

a. Performance measurement didefinisikan sebagai proses mengukur efisiensi dan efektivitas tindakan.

b. A performance measure didefinisikan sebagai matriks yang digunakan untuk mengukur efisiensi dan/atau efektivitas dari suatu tindakan.

c. A performance measurement system didefinisikan sebagai sekumpulan matriks yang digunakan untuk mengukur baik untuk efisiensi dan efektivitas tindakan.

Pengukuran kinerja tradisional merupakan pengukuran yang dilakukan pada aspek yang berkaitan dengan keuangan sehingga pengukuran kinerja seperti peningkatan kompetensi, peningkatan produktivitas, dan efektifitas biaya proses bisnis yang digunakan untuk melayani pelanggan selalu diabaikan. Hal ini merupakan salah satu kelemahan utama dari sistem pengukuran kinerja yang digunakan oleh banyak perusahaan yang berpikir sempit dalam melakukan penilaian kinerja yang fokus pada satu dimensi [7].

\subsection{Metode-metode Pengukuran Kinerja}

Sejumlah kerangka kerja dan model untuk melakukan pengukuran kinerja telah dikembangkan sejak tahun 1980an. Kerangka kerja dan model yang dikembangkan memiliki manfaat masing-masing dalam melakukan pengukuran kinerja [6].

Berbagai perusahaan mencoba untuk mengadopsi berbagai macam kerangka sistem manajemen kinerja yang telah dikenal oleh para ahli secara luas pada dekade terakhir [8] seperti SMART (Strategic Management Analysis and Reporting Technique), 
PMQ (Performance Measurement Questionnaire), PWCM (Performances For World Class Manufacturing), QPMM (Quantum Performances Measurement Model), BSC (The Balanced Scorecard) dan Prism.

Metode-metode pengukuran kinerja dalam memberikan penilaian perusahaan mempertimbangkan aspek-aspek penting lainnya yang menjadi lingkup aktivitas perusahaan seperti kualitas produk yang dihasilkan dan kepuasan pelanggan. Selain itu, metode-metode tersebut juga berusaha untuk mengontrol sistem manajemen perusahaan agar tujuan perusahaan dapat tercapai.

\subsection{Balanced Scorecard}

Konsep balanced scorecard pertamakali diperkenalkan oleh Robert S. Kaplan dan David P. Norton pada tahun 1992 dan telah diadopsi oleh perusahaan manufaktur, jasa, organisasi nirlaba, dan lembaga pemerintahan diseluruh dunia [4]. Sebelum adanya konsep balanced scorecard pengukuran kinerja dilakukan dengan pendekatan tradisional, yang menjadi ukurannya adalah aspek keuangan perusahaan dan seiring berjalannya waktu para pimpinan menyadari bahwa tidak ada ukuran tunggal yang dapat memberikan target kinerja yang jelas dan fokus pada daerah yang kritis di perusahaan [9].

Balanced scorecard menampilkan kerangka kerja yang komprehensif sehingga dapat menterjemahkan tujuan strategis perusahaan kedalam ukuran kinerja sehingga dapat membantu perusahaan untuk fokus terhadap visinya. Dan ini merupakan alat yang dapat digunakan untuk memantau kinerja perusahaan sehingga dapat disusun strategi untuk meningkatkan kemampuan perusahaan [10].

Dalam konsep balanced scorecard untuk penilaian perusahaan secara tradisional yang dilakukan dengan melihat pada perspektif keuangan ditambahkan dalam konsep balanced scorecard menjadi perspektif pelanggan, proses internal, dan inovasi \& pertumbuhan. Sehingga dengan keempat perspektif balanced scorecard dapat menunjukkan keseimbangan pada perspektif yang diukur, yaitu antara perspektif finansial dan non-finansial sehingga memungkinkan manajer untuk melihat bisnis pada perspektif tersebut [9]. Dari keempat perspektif tersebut dapat menjawab pertanyaan sebagai berikut:

1. Perspektif pelanggan, yaitu untuk menjawab pertanyaan bagaimana pelanggan memandang perusahaan.

2. Perspektif internal, untuk menjawab pertanyaan pada bidang apa perusahaan memiliki keahlian.

3. Perspektif inovasi dan pembelajaran, untuk menjawab pertanyaan apakah perusahaan mampu berkelanjutan dan menciptakan nilai.

4. Perspektif keuangan, untuk menjawab pertanyaan bagaimana perusahaan memandang pemegang saham. 
Balanced Scorecard menggambarkan keseimbangan hubungan-hubungan perspektif pengukuran tersebut pada Gambar 1.

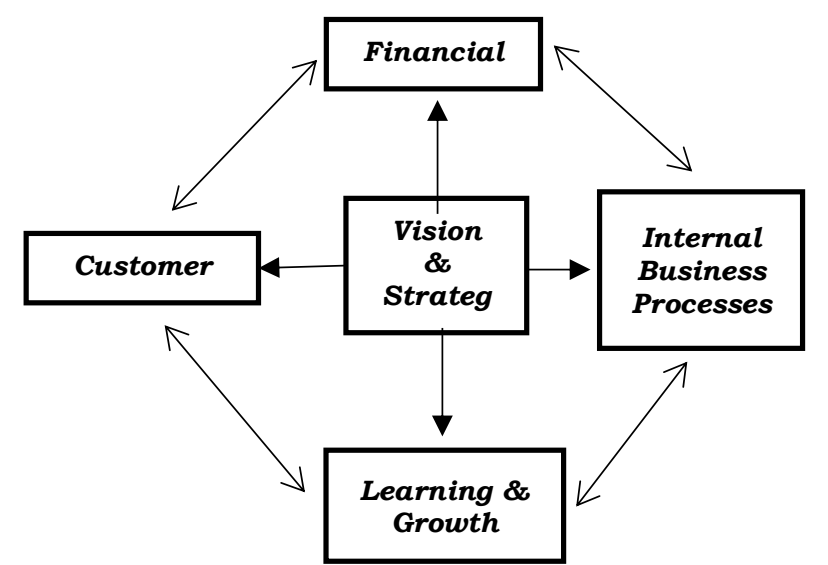

Gambar 1. Implementasi Balanced Scorecard

Penerapan balanced scorecard di perusahaan dapat memberikan manfaat seperti (1) dapat menentukan prioritas perencanaan dan kebutuhan penilaian masa depan. (2) memberikan struktur yang jelas untuk perbaikan mutu berkelanjutan. (3) dapat membangun budaya mutu di antara divisi-divisi. (4) dapat mengevaluasi penggunaan sumber daya yang efisien, dan (5) memberikan dokumentasi sebagai konstribusi masing-masing divisi terhadap misi dari perusahaan tersebut yang dapat digunakan [10].

\section{Metodologi}

\subsection{Pengumpulan Data}

Data primer yang dibutuhkan dalam penelitian ini adalah melakukan survei lapangan untuk mengetahui permasalahan yang ada di PT. Inti Isawit Subur. Selanjutnya akan dilakukan perancangan kuisioner untuk menentukan KPI yang akan digunakan dalam pengukuran sistem penilaian kinerja di PT. Inti Isawit Subur dengan melibatkan pimpinan perusahaan. Kuisioner yang akan digunakan diperoleh dari hasil Focus Group Discussion (FGD) dengan pimpinan di PT. Inti Isawit Subur. Perancangan kuisioner ini merupakan tahap awal sebelum expert memberikan penilaian terhadap KPI yang akan digunakan oleh perusahaan.

Setelah kuisioner hasil FGD dengan pimpinan diperoleh, selanjutnya akan disebarkan untuk diberikan penilaian. Penialain ini bertujuan untuk mengeliminasi KPI yang tidak memberikan peningkatan untuk perusahaan disaat ini.

\subsection{Perancangan Sistem Penilaian Kinerja}

Langkah-langkah dalam melakukan perancangan sistem penilaian kinerja di PT. Inti Isawit Subur adalah sebagai berikut:

1. Mengidentifikasi key performance indikator (KPI) untuk perusahaan berdasarkan Visi dan Misi PT. Inti Isawit Subur dan dibuatkan dalam bentuk kuisioner penilaian dengan tujuan pemilihan indikator yang memberikan pengaruh terhadap peningkatan kinerja perusahaan. Kuisioner disebarkan kelima orang pakar yang ada di PT. Inti Isawit Subur. Hasil penilaian kelima pakar dirata-ratakan. Nilai rata-rata ini digunakan untuk mengeliminasi indikator yang memiliki pengaruh kecil terhadap penilaian kinerja perguruan tinggi dengan melakukan cut off point, nilai rata-rata maksimal dijumlahkan dengan nilai rata-rata minimal dibagi dua, apabila nilai ratarata kecil dari hasil cut off point maka indikator tersebut dieliminasi. 
2. Melakukan validasi key performance indikator (KPI) kepada General Manager Profesional setelah memperoleh indikator terpilih untuk selanjutnya dilakukan perancangan dalam bentuk balanced scorecard.

3. Perancangan penilaian kinerja dalam bentuk balanced scorecard dilakukan bersama-sama dengan pakar dari PT. Inti Isawit Subur.

\subsection{Analisis Hasil}

Analisis dilakukan terhadap hasil perancangan sistem penilaian kinerja dengan metode blanced scorecard yang dapat digunakan oleh perusahaan.

\subsection{Kesimpulan}

Kesimpulan merupakan tahap akhir dari penelitian perancangan sistem penilaian kinerja di PT. Inti Isawit Subur. Kesimpulan yang dipaparkan adalah hasil perancangan sistem penilaian kinerja dengan metode blanced scorecard.

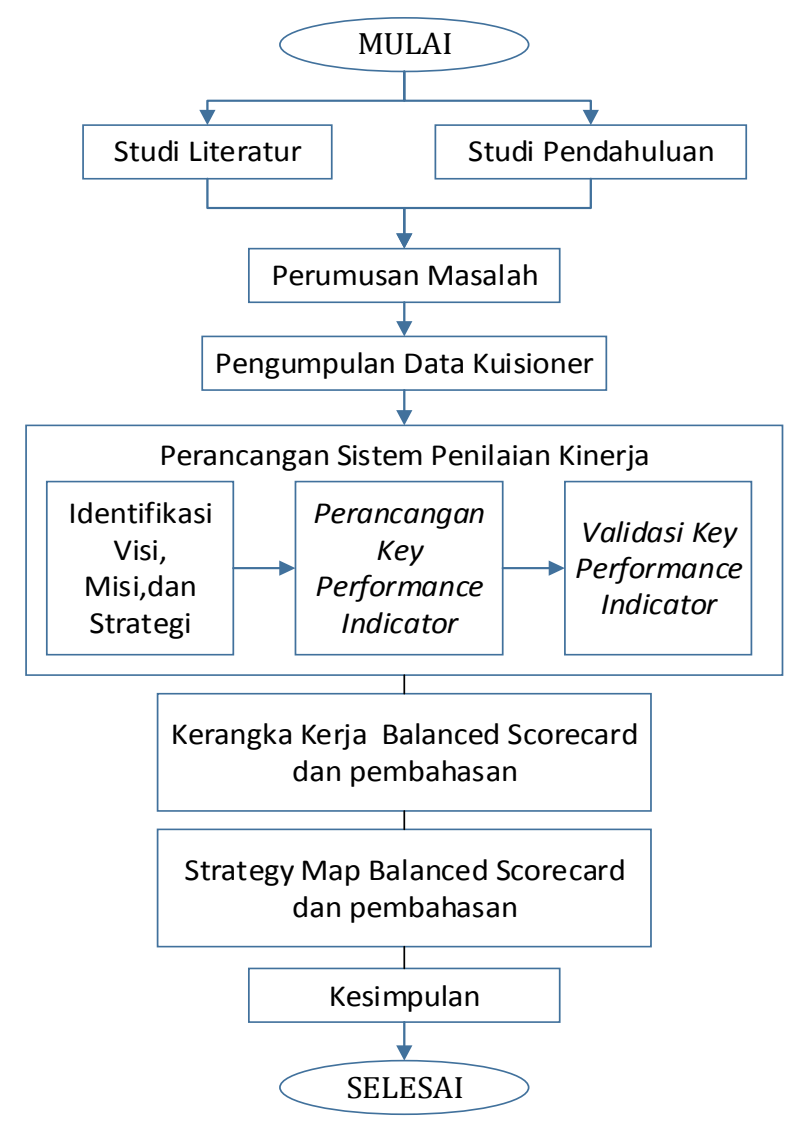

Gambar 2. Flowchart Penelitian

\section{Hasil dan Pembahasan}

\subsection{Rancangan Kuisioner Key Performance Indicator}

Menyusun indikator kinerja bagi perusahaan merupakan tahap awal dalam penelitian ini. Langkah ini dimaksudkan untuk menetapkan hal-hal apa saja yang diperlukan untuk mengukur sebuah sistem pengukuran kinerja. Rancangan usulan indikator kinerja tersebut dapat dilihat pada Tabel 1 dan data ukuran rancangan usulan 
indicator kinerja didapat dan ditetapkan oleh kepada General Manager Profesional PT. Inti Isawit subur.

Tabel 1. Rancangan kuisioner KPI Blanced Scorecard

\begin{tabular}{|c|c|c|c|c|c|}
\hline \multirow{2}{*}{ Perspektif } & \multirow{2}{*}{ KPI } & \multirow{2}{*}{ Measure } & \multicolumn{3}{|c|}{ NILAI } \\
\hline & & & 1 & 2 & 3 \\
\hline \multirow{3}{*}{$\begin{array}{l}\frac{\bar{\sigma}}{0} \\
\frac{\sigma}{\sigma} \\
i \\
i\end{array}$} & 1. Meningkatkan profit & $2 \%$ per-tahun & & & \\
\hline & 2. Meningkatkan investasi & Rp. 1 Miliyar per tahun & & & \\
\hline & 3. Meningkatkan efisiensi biaya & Rp. 500 Juta per tahun & & & \\
\hline \multirow{3}{*}{$\begin{array}{l}\frac{v}{0} \\
\frac{5}{0} \\
\frac{D}{0} \\
0\end{array}$} & $\begin{array}{l}\text { 1. Meningkatkan Kepuasan } \\
\text { konsumen }\end{array}$ & $\begin{array}{l}0 \text { komplain dari konsumen } \\
\text { per tahun }\end{array}$ & & & \\
\hline & 2. Loyalitas konsumen & $\begin{array}{l}0 \text { konsumen yang hilang } \\
\text { per tahun }\end{array}$ & & & \\
\hline & 3. Bertambah jumlah konsumen & 1 perusahaan per tahun & & & \\
\hline \multirow{4}{*}{ 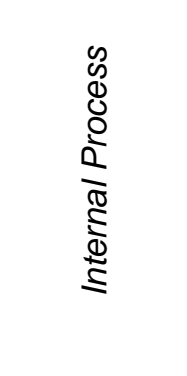 } & 1. Meningkatkan jumlah produksi & 5 Ton TBS per tahun & & & \\
\hline & $\begin{array}{l}\text { 2. Mengurangi tingkat kecelakaan } \\
\text { kerja }\end{array}$ & $\begin{array}{c}\text { Min } 2 \text { kecelakaan kerja per } \\
\text { tahun }\end{array}$ & & & \\
\hline & 3. Kehadiran karyawan & $90 \%$ per tahun & & & \\
\hline & $\begin{array}{l}\text { 4. Mengurangi jumlah } \\
\text { keterlambatan }\end{array}$ & 5 Keterlambatan per tahun & & & \\
\hline \multirow{3}{*}{ 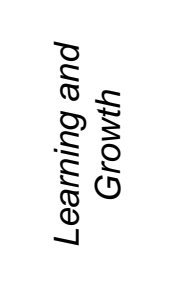 } & $\begin{array}{l}\text { 1. Meningkatkan Kepuasan } \\
\text { pegawai }\end{array}$ & $90 \%$ per tahun & & & \\
\hline & $\begin{array}{l}\text { 2. Meningkatkan kompetensi } \\
\text { pegawai }\end{array}$ & $\begin{array}{l}5 \text { Jumlah pelatihan per } \\
\text { tahun }\end{array}$ & & & \\
\hline & 3. Penghargaan & 3 orang per tahun & & & \\
\hline
\end{tabular}

\section{Sumber: Pengolahan Data Berdasarkan FGD}

\subsection{Kuesioner Penilaian}

Kuesioner yang berisi kriteria-kriteria yang sudah dirancang pada Tabel 1, dibagikan ke responden yang merupakan expert yang memiliki pengalaman dan keahlian di bidang masing-masing. Penilaian dibagi menjadi tiga bagian yaitu satu elemen dinilai sangat penting (very important) maka akan diberi skor 3, cukup penting (somewhat important) diberi nilai 2, dan tidak penting (not important) diberi nilai 1.

Seluruh penilaian responden dikumpulkan, kemudian dirata-ratakan untuk setiap elemen. Seluruh kriteria diurutkan dari nilai tertinggi ke nilai terendah.

Berikut ini adalah langkah-langkah pengolahan data dengan menggunakan metode Cutoff Point: 


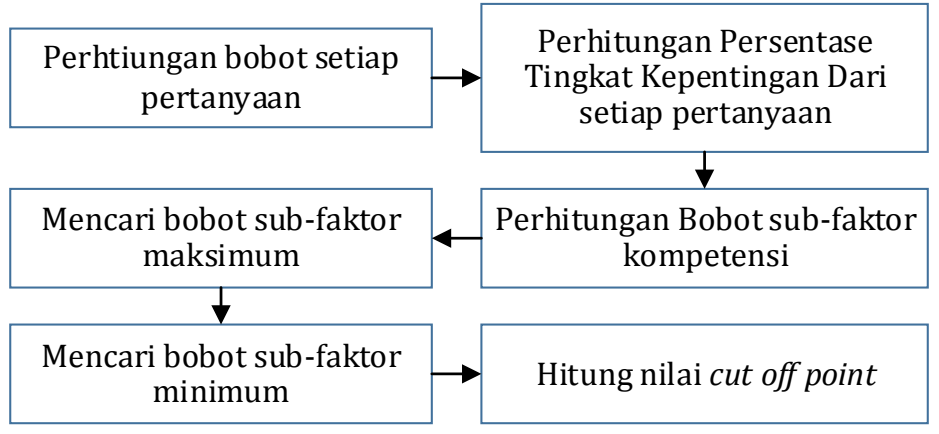

Gambar 3. Langkah cut off point

Perhitungan metode Cut Off - Point yang memiliki nilai di bawah cut off point akan dibuang dari perhitungan yang dilakukan. Formulasi Cut Off - Point:

$$
\text { Cut Off Point }=\frac{\text { Max Score }+ \text { Min Score }}{2} \quad \text { Pers. } 1
$$

Hasil dari penilaian expert dihitung nilai rata-rata maksimum adalah 2,8 sedangkan nilai rata-rata minimum adalah 1,4 sehingga natural cut off point adalah :

$$
\text { Cut Off Point }=\frac{2,8+1,4}{2}=2,1
$$

Maka faktor-faktor dengan nilai rata-rata $\leq 2,1$ akan di eliminasi dari Key Performance Indicator. Dapat dilihat pada Tabel 2.

\begin{tabular}{|c|c|c|c|c|c|c|c|}
\hline \multirow{2}{*}{$\begin{array}{l}\text { t } \\
\text { d } \\
\frac{0}{0} \\
\frac{0}{0} \\
0\end{array}$} & \multirow[b]{2}{*}{ KPI } & \multicolumn{5}{|c|}{ Expert } & \multirow[b]{2}{*}{ Rata-rata } \\
\hline & & 1 & 2 & 3 & 4 & 5 & \\
\hline \multirow{3}{*}{ 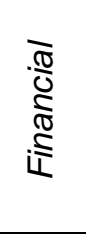 } & Meningkatkan profit & 3 & 3 & 2 & 3 & 3 & 2,8 \\
\hline & Meningkatkan investasi & 2 & 2 & 3 & 3 & 1 & 2,2 \\
\hline & $\begin{array}{l}\text { 3. Meningkatkan efisiensi } \\
\text { biaya }\end{array}$ & 2 & 1 & 1 & 2 & 1 & 1,4 \\
\hline \multirow{3}{*}{ 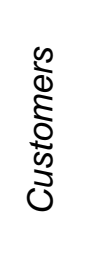 } & $\begin{array}{l}\text { 1. Meningkatkan Kepuasan } \\
\text { konsumen }\end{array}$ & 3 & 3 & 3 & 3 & 2 & 2,8 \\
\hline & Loyalitas konsumen & 3 & 3 & 3 & 3 & 2 & 2,8 \\
\hline & $\begin{array}{l}\text { 3. Bertambah jumlah } \\
\text { konsumen }\end{array}$ & 3 & 3 & 1 & 3 & 3 & 2,6 \\
\hline \multirow{3}{*}{ 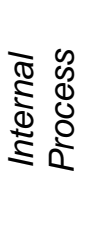 } & $\begin{array}{l}\text { 1. Meningkatkan jumlah } \\
\text { produksi }\end{array}$ & 3 & 2 & 2 & 2 & 3 & 2,4 \\
\hline & $\begin{array}{l}\text { 2. Mengurangi tingkat } \\
\text { kecelakaan kerja }\end{array}$ & 2 & 3 & 1 & 2 & 3 & 2,2 \\
\hline & 3. Kehadiran karyawan & 3 & 2 & 2 & 3 & 3 & 2,6 \\
\hline
\end{tabular}

Tabel 2. Rekapitulasi Nilai Cut off Point 


\begin{tabular}{|c|c|c|c|c|c|c|c|c|}
\hline & 4. & $\begin{array}{l}\text { Mengurangi jumlah } \\
\text { keterlambatan }\end{array}$ & 2 & 1 & 1 & 2 & 1 & 1,4 \\
\hline \multirow{3}{*}{ 点 } & 1. & $\begin{array}{l}\text { Meningkatkan Kepuasan } \\
\text { pegawai }\end{array}$ & 3 & 2 & 3 & 2 & 2 & 2,4 \\
\hline & 2. & $\begin{array}{l}\text { Meningkatkan kompetensi } \\
\text { pegawai }\end{array}$ & 3 & 1 & 2 & 3 & 2 & 2,2 \\
\hline & 3. & Penghargaan & 3 & 3 & 3 & 3 & 2 & 2,8 \\
\hline
\end{tabular}

Sumber: Pengolahan Data Berdasarkan Kuesioner

Dari perhitungan nilai cut off point dapat diketahui tingkat kepentingan dari setiap KPI dalam perspektif yang di pilih oleh expert. Dapat dilihat pada Tabel 3.

Tabel 3. Rekapitulasi KPI Terpilih

\begin{tabular}{cl}
\hline Perspektif & \multicolumn{1}{c}{ KPI } \\
\hline Financial & $\begin{array}{l}\text { 1. Meningkatkan profit } \\
\text { 2. Meningkatkan Investasi }\end{array}$ \\
\hline Customers & $\begin{array}{l}\text { 1. Meningkatkan kepuasan konsumen } \\
\text { 2. Loyalitas konsumen } \\
\text { 3. Bertambah jumlah konsumen }\end{array}$ \\
\hline Internal & $\begin{array}{l}\text { 1. Meningkatkan jumlah produksi } \\
\text { 2. Mengurangi tingkat kecelakaan }\end{array}$ \\
& 3. Kerja \\
Learning & 1. Meningkatkan kepuasan pegawai \\
and Growth & 3. Meningkatkan kompetensi pegawai \\
& 3. Penghargaan \\
\hline Sumber: Pengolahan Data Berdasarkan Kuesioner
\end{tabular}

Dari $13 \mathrm{KPI}$ yang di usulkan ke expert, diperoleh $11 \mathrm{KPI}$ yang terpilih setelah dilakukanya penilaian oleh tim expert dan $2 \mathrm{KPI}$ yang tereliminasi. KPI yang tereliminasi, 1 dari perspektif financial, dan 1 perspektif dari internal process.

\subsection{Kerangka Kerja Balanced Scorecard}

Balanced Scorecard melengkapi seperangkat ukuran finansial kinerja masa lalu dengan ukuran kinerja masa depan. Tujuan dan ukuran scorecard diturunkan dari visi dan strategi. Tujuan dan ukuran memandang kinerja perusahaan dari empat perspektif. Empat perspektif ini memberi kerangka kerja bagi Balanced Scorecard. Kerangka kerja Balanced Scorecard untuk PT. Inti Isawit Subut dapat dilihat pada Gambar 4. 


\begin{tabular}{|c|c|}
\hline \multicolumn{2}{|c|}{ FINANCIAL } \\
\hline KPI & MEASURE \\
\hline $\begin{array}{c}\text { Meningkatkan } \\
\text { Profit }\end{array}$ & $2 \%$ per tahun \\
\hline $\begin{array}{c}\text { Meningkatkan } \\
\text { Investasi }\end{array}$ & 1 Miliyar per tahun \\
\hline
\end{tabular}

\begin{tabular}{|c|c|}
\hline \multicolumn{2}{|c|}{ CUSTOMERS } \\
\hline KPI & MEASURE \\
\hline $\begin{array}{c}\text { Meningkatkan } \\
\text { kepuasan } \\
\text { konsumen }\end{array}$ & $\begin{array}{c}\text { 0 komplain dari } \\
\text { konsumen per } \\
\text { tahun }\end{array}$ \\
\hline $\begin{array}{c}\text { Loyalitas } \\
\text { Konsumen }\end{array}$ & $\begin{array}{c}\text { 0 konsumen yang } \\
\text { hilang per tahun }\end{array}$ \\
\hline $\begin{array}{c}\text { Bertambah jumlah } \\
\text { konsumen }\end{array}$ & $\begin{array}{c}1 \text { perusahaan per } \\
\text { tahun }\end{array}$ \\
\hline
\end{tabular}

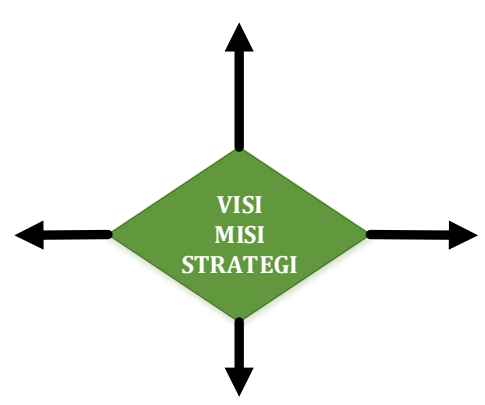

\begin{tabular}{|c|c|}
\hline \multicolumn{2}{|c|}{ INTERNAL PROCESS } \\
\hline KPI & MEASURE \\
\hline $\begin{array}{c}\text { Meningkatkan } \\
\text { jumlah produksi }\end{array}$ & $\begin{array}{c}5 \text { ton TBS per } \\
\text { tahun }\end{array}$ \\
\hline $\begin{array}{c}\text { Mengurangi } \\
\text { tingkat kecelakaan } \\
\text { kerja }\end{array}$ & $\begin{array}{c}\text { Min. 2 kecelakaan } \\
\text { kerja per tahun }\end{array}$ \\
\hline $\begin{array}{c}\text { Kehadiran } \\
\text { karyawan }\end{array}$ & $90 \%$ per tahun \\
\hline
\end{tabular}

\begin{tabular}{|c|c|}
\hline \multicolumn{2}{|c|}{ LEARNING AND GROWTH } \\
\hline KPI & MEASURE \\
\hline $\begin{array}{c}\text { Meningkatkan } \\
\text { kepuasan pegawai }\end{array}$ & $90 \%$ per tahun \\
\hline $\begin{array}{c}\text { Meningkatkan } \\
\text { kompetensi } \\
\text { pegawai }\end{array}$ & $\begin{array}{c}5 \text { pelatihan per } \\
\text { tahun }\end{array}$ \\
\hline Penghargaan & 3 orang per tahun \\
\hline
\end{tabular}

Gambar 4. Kerangka Kerja Balanced Scorecard Di PT. Inti Isawit Subur

Setiap kotak memiliki tujuan, ukuran, target, dan inisiatif. Seluruh kotak tersebut dihubungkan dengan anak panah untuk mengilustrasikan bahwa tujuan dan ukuran dari keempat perspektif tersebut dikaitkan dengan hubungan sebab dan akibat. Mencapai target pada suatu perspektif seharusnya mengarah pada perbaikan yang diinginkan pada perspektif berikutnya, dan begitu seterusnya, sehingga kinerja perusahaan meningkat secara keseluruhan yang berdampak pada peningkatan profit perusahaan.

\subsection{Strategy MAP Balanced Scorecard}

Strategy map dapat dilihat pada Gambar 5 yang menggambarkan hubungan strategi organisasi yang berawal dari masing-masing perspektif dalam Balanced Scorecard. Strategy map di PT. Inti Isawit Subur berawal dari perspektif learning \& growth dengan strategi meningkatkan Kepuasan pegawai, meningkatkan kompetensi pegawai dan memberikan penghargaan. Indikator ini memberikan efek terhadap hasil kerja seluruh karyawan dalam melaksanakan tugasnya dan selanjutnya akan berpengaruh terhadap pencapaian pada perspektif internal process. 
STRATEGI MAP

PT. INTI ISAWIT SUBUR

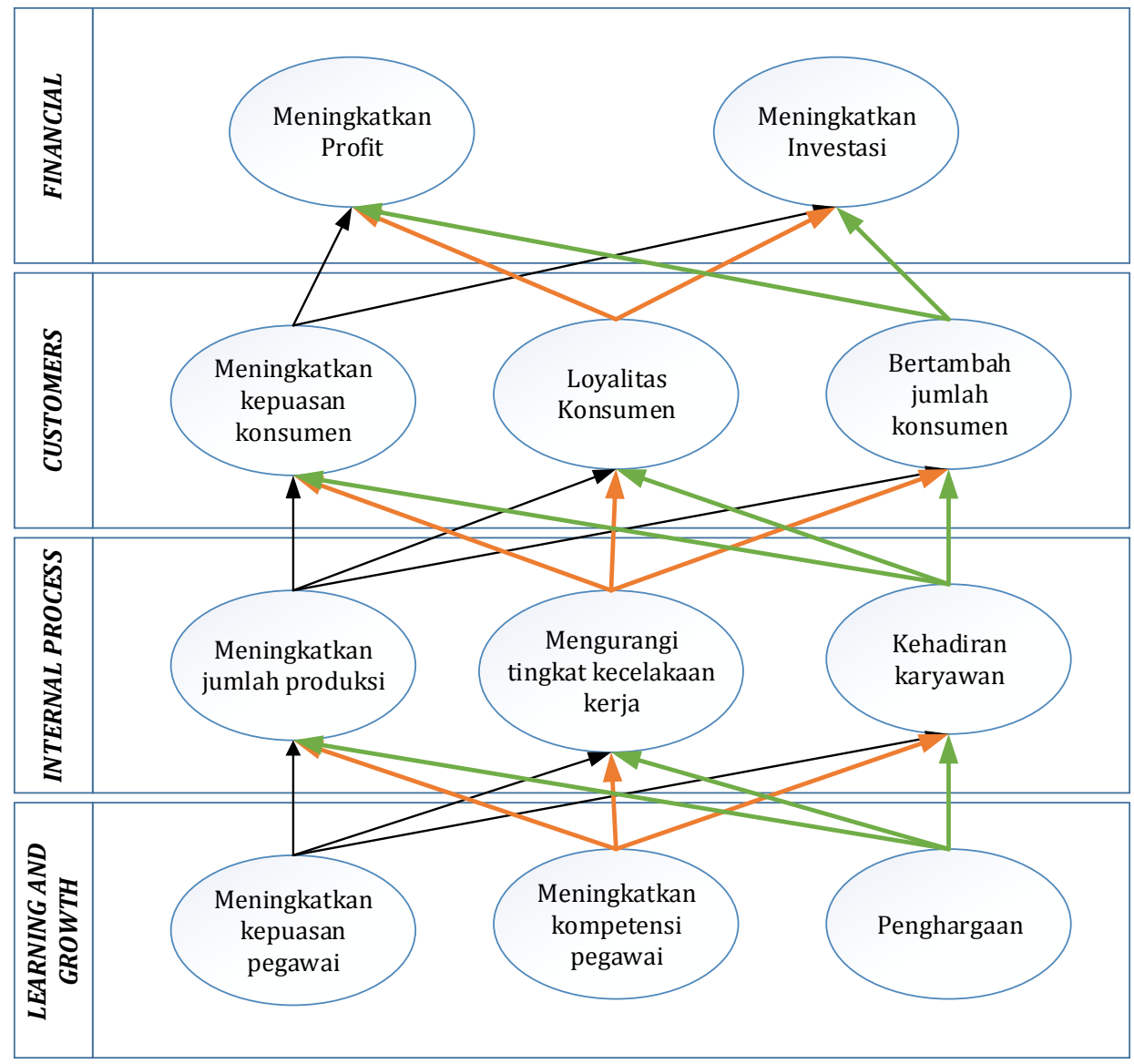

Gambar 6. Strategy Map Balanced Scorecard Di PT. Inti Isawit Subur

Perspektif internal process yang terdiri dari indikator meningkatkan jumlah produksi, mengurangi tingkat kecelakaan kerja, dan meningkatkan kehadiran karyawan akan mempengaruhi perspektif customers. Hal ini dikarenakan dengan meningkatkan jumlah produksi, mengurangi tingkat kecelakaan kerja, dan meningkatkan kehadiran karyawan akan memudahkan bagi perusahaan untuk memenuhi permintaan konsumen dan konsumen tidak perlu membeli hasil minyak sawit di perusahaan lain, sehingga konsumen lebih loyal terhadap perusahaan dan memberikan kesan baik terhadap konsumen lainnya.

Perspektif customers yang terdiri dari indikator meningkatkan kepuasan konsumen, loyalitas konsumen, dan bertambahnya jumlah konsumen akan berpengaruh terhadap perspektif financial. Hal ini dikarenakan dengan meningkatkan kepuasan konsumen, loyalitas konsumen, dan bertambahnya jumlah konsumen akan menambah profit bagi perusahaan. Selain itu akan memberikan peluang untuk pengusaha lain berinvestasi ke perusahaan PT. Inti Isawit subur karena manajemen dan pelayanan terhadap kosumen yang baik.

Perspektif financial yang terdiri dari meningkatkan profit dan meningkatkan investasi dapat terlaksana jika persfektif learning and growth, perspektif internal process, dan perspektif customers dapat dijalankan dengan baik oleh pimpinan PT. Inti Isawit Subur.

Dengan adanya sistem penilaian kinerja di PT. Inti Isawit Subur akan membantu pimpinan untuk mengontrol kinerja perusahaanya, sehingga dapat diketahui kelemahan dari perusahaan yang perlu dilakukan perbaikan dan peningkatan. Selain itu dapat juga 
digunakan untuk penilaian dalam meningkatkan jenjang karir bagi pegawai PT. Inti Isawit Subur

\section{Kesimpulan}

Perancangan key performance indicators sistem penilaian kinerja di PT. Inti Isawit Subur dapat digunakan indikator-indikator berdasarkan perspektif yang ada dalam Balanced Scorecard yang telah dirancang. Dengan adanya sistem penilaian kinerja dapat memudahkan pimpinan dalam mengontrol kinerja perusahaanya sehingga dapat cepat dalam melakukan perbaikan dan peningkatan kinerja di perusahaan.

Perancangan sistem penilaian kinerja dapat dilanjutkan dengan menghitung nilai setiap indikator yang ada dalam balanced scorecard yang telah dirancang. Dengan adanya penilaian akan memudahkan untuk menghitung nilai keseluruhan kinerja di PT. Inti Isawit Subur.

Untuk penelitian selanjutnya dapat dilakukan perhitungan bobot untuk setiap KPI yang diperoleh dengan menggunakan metode Analytical Hierarchy Process (AHP). Dengan menggunakan metode ini dapat diketahui KPI yang menjadi prioritas perusahaan untuk di tingkatkan.

\section{Daftar Pustaka}

[1] Isnuwardiati, K. Dan Sugito, P. (2018) Pengaruh Demand Chain Management terhadap Daya Saing. Conference on Innovation and Application of Science and Technology. Pp. $21-30$

[2] Sayed, N. (2013). Ratify, reject or revise: balanced scorecard and universities. International Journal of Educational Management. Vol. 27 No. 3, pp. 203-220.

[3] Arijanto, S., dan Harsono. A. R. (2010). Pengukuran Kinerja Fakultas Di Perguruan Tinggi "X" Menggunakan Pendekatan Macom Baldrige Criteria For Performance Excellence (Education Criteria). Proceeding Seminar Nasional IV Manajemen dan Rekayasa Kualittas. Institut Teknologi Nasional. Bandung.

[4] Kaplan, R., and Norton, D. (2001). Transforming the Balanced Scorecard from Performance Measurement to Strategic Management: Part I. Accounting Horizons. Vol. 15 No.1. pp. 87-104.

[5] Zeglat, D., Alrawabdeh, W., Almadi, F., dan Shrafat, F. (2012). Performance Measurements Systems: Stages of Development Leading to Success. Interdiciplinary Journal of Contemporary Research in Business. Vol. 4 No. 7. The Hashemite University. Jordan.

[6] David, R., dan E, J. J. (2014). Study On Performance Measurement Systems Measures and Metrics. International Jurnal of Scientific and Research Publications. Vol. 4, Issue 9. SCMS School of Engineering and Technology. India.

[7] Neely, A., Bourne, M., dan Kennerley, M. (2000). Performance Measurement System Design: Developing and Testing a Process-Based Approach. International Journal of Operations \& Productions Management. Vol. 20 No. 10, pp. 1119-1145. University Press.

[8] Wibisono, D. (2006). Manajemen kinerja: Konsep, Desain, dan Teknik Meningkatkan Daya Saing Perusahaan. Erlangga: Jakarta.

[9] Kaplan, R., and Norton, D. (1992). The Balanced Scorecard: Measures That Drive Performance. Harvard Business Review. Vol. 70 No. 1, pp. 71-9.

[10] Al-Hosaini, F. F., dan Sofian, S. (2015). A Review of Balanced Scorecard Framework in Higher Education Institution. International Review of Management and Marketing. Vol. 5 No.1, pp. 23-35. 